\title{
Proceeding Paper \\ Simulating the Impact of Solar Energy on Pyramid and Stair Urban Blocks ${ }^{\dagger}$
}

\author{
Gloria Pignatta ${ }^{1, *} \mathbb{0}$, Haniya Javed ${ }^{1}$, Mehrangiz Mastoori ${ }^{2, *}$, Seyede Najme Sharifi ${ }^{3}$, \\ Naga Venkata Sai Kumar Manapragada 4 (D) and Cinzia Buratti ${ }^{5}$ \\ 1 School of Built Environment, Faculty of Arts, Design and Architecture, University of New South \\ Wales (UNSW), Sydney, NSW 2025, Australia; h.javed@unsw.edu.au \\ 2 Department of Art and Architecture, Rouzbahan University, Sari, Mazandaran 48179-39945, Iran \\ 3 Department of Art and Architecture, IslamicAzad University of Shiraz, Shiraz 71987-74731, Iran; \\ s.najmesharifi@gmail.com \\ 4 Manipal School of Architecture and Planning, Manipal Academy of Higher Education (MAHE), \\ Manipal 576104, India; nagavsk.m@manipal.edu \\ 5 Department of Engineering, University of Perugia, 06125 Perugia, Italy; cinzia.buratti@unipg.it \\ * Correspondence: g.pignatta@unsw.edu.au (G.P.); meh.mastoori@gmail.com (M.M.) \\ + Presented at the 3rd Built Environment Research Forum, Sydney, Australia, 1 December 2021.
}

Citation: Pignatta, G.; Javed, H.;

Mastoori, M.; Sharifi, S.N.;

Manapragada, N.V.S.K.; Buratti, C.

Simulating the Impact of Solar Energy

on Pyramid and Stair Urban Blocks.

Environ. Sci. Proc. 2021, 12, 4.

https: / / doi.org/10.3390/

environsciproc2021012004

Academic Editor: Khan Rahmat Ullah

Published: 15 December 2021

Publisher's Note: MDPI stays neutral with regard to jurisdictional claims in published maps and institutional affiliations.

Copyright: (c) 2021 by the authors. Licensee MDPI, Basel, Switzerland. This article is an open access article distributed under the terms and conditions of the Creative Commons Attribution (CC BY) license (https:/ / creativecommons.org/licenses/by/ $4.0 /)$.

\begin{abstract}
Developing countries such as Iran are rapidly expanding, putting pressure on nonrenewable energy resources. The building sector takes a major share of the total energy consumption of the country and is projected to increase further, resulting in the call for strategies to reduce energy use by improving the thermal performance of buildings. This study addresses the compelling need to provide optimum design guidelines for future apartment buildings in the city of Shiraz by investigating two urban cluster typologies, stair and pyramid, arranged in five orientations. The results showcase the ideal combination of $155^{\circ}$ for the Pyramid typology, which contributes the least to the annual energy loads of the buildings.
\end{abstract}

Keywords: energy consumption; solar access; urban cluster; residential apartments; radiance simulation; built environment; Iran

\section{Introduction}

In Iran, the building sector is a significant user of energy, accounting for 33\% of the total energy consumption [1]. Fossil fuel-based energy use [2] is expected to rise due to the growing population that resides in apartment buildings in urban areas [3]. Highperformance residential apartment design can improve the overall urban energy efficiency through solar urban design [4].

Existing examples of urban design research for Iran include the impact analysis of building form and orientation on the thermal performance of apartment buildings [5] and the social aspects of urban morphology [3]. Many international studies have explored solar urban design by investigating the impact of overshadowing [6], orientation, building heights, density, and the cluster grid [7] on the solar capture potential while attempting to define a template for efficient future urban design [8].

This study has been built on previous local and international research and aims to investigate two specific urban block typologies: the stair and pyramid. Five orientation scenarios have been chosen and investigated to determine the optimal design solution in terms of thermal performance and energy use.

Iran presents values of solar radiation that are higher than the global average [9]. The city of Shiraz has been selected to perform this analysis, as it experiences warm arid climate conditions with high solar irradiation of $5.8-6.2 \mathrm{kWh} / \mathrm{m}^{2}$, which is on the higher end of the solar irradiation range received by Iran [10]. 


\section{Methodology}

The proposed orientation scenarios were preliminarily modelled in Ecotect [11] as solid rectangular towers without openings to isolate the influence of the urban clustering layout on the solar capture potential of the building surfaces for each typology. As shown in Table 1 , the building blocks are arranged in five orientations of $0^{\circ}, 45^{\circ}, 90^{\circ}, 135^{\circ}$, and $155^{\circ}$, for which the two urban typologies of stair and pyramid are assessed in a linear arrangement of five towers.

Table 1. Solar access and shadowing for the stair and pyramid typology oriented at $0^{\circ}, 45^{\circ}, 90^{\circ}, 135^{\circ}$, and $155^{\circ}$, respectively.

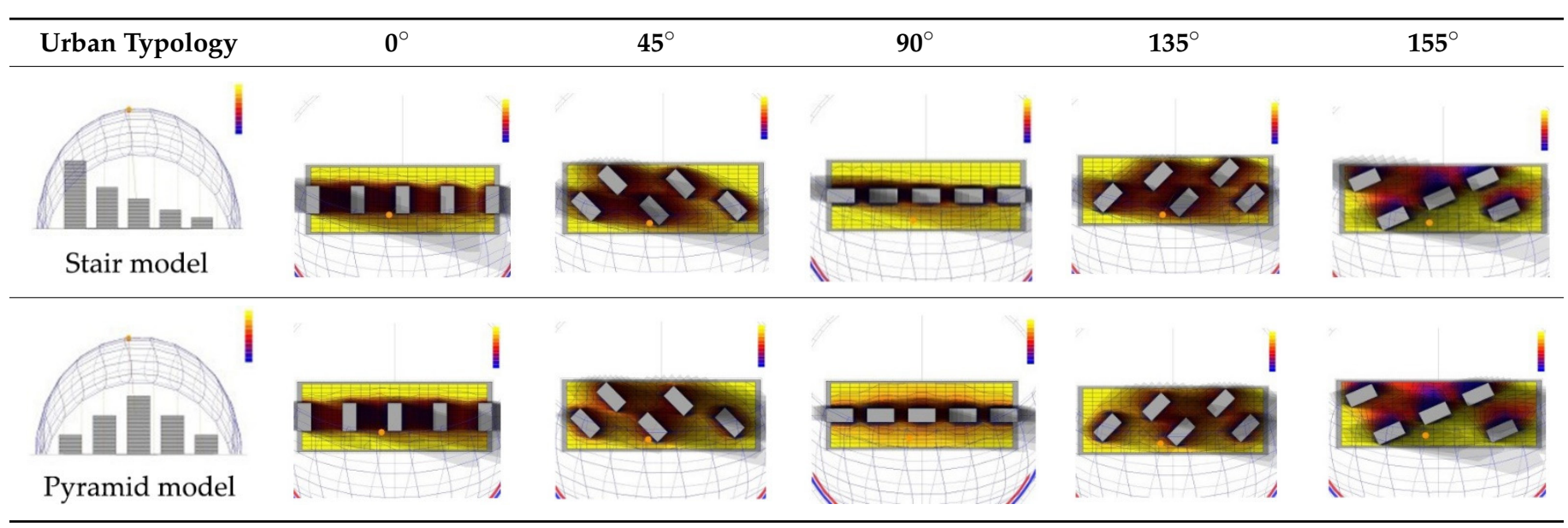

The simulated blocks include 45 residential units that have been arranged and designed in a site area of $7000 \mathrm{~m}^{2}$. The layout of the units is based on the optimum proportion of 1:2, which was determined based on daylight penetration [12], resulting in each unit being $10 \mathrm{~m}$ long, $20 \mathrm{~m}$ wide, and $3 \mathrm{~m}$ in height, with 1 unit on each floor. The distance between the blocks is 1.5 times the height to allow the desired daylight levels, according to the regulations of the Iran Urbanism and Architectural Supreme Council [13] for high-rise density and construction.

As brick has traditionally been used as an appropriate material for the climate of Shiraz [14], it was therefore selected as the building material for the simulated apartment blocks. A mixed-mode space conditioning system for cooling, heating, and fresh air supply has been chosen to provide indoor thermal comfort temperature for the occupants. Additionally, four sitting and standing occupants (two adults and two children) per block have been considered in the model to assess the heat that is generated by occupant activities.

The weather data for Shiraz have been obtained from Meteonorm [15].

Sunlight accessibility and surface absorption have been analyzed through a schematic shadow analysis of the proposed layouts along with the annual energy demand for each urban block and orientation scenario. Simulation results have been assessed to recognise the most optimum urban layout and material combination.

\section{Results}

\subsection{Shadow Analysis and Solar Intensity}

Table 1 compares the solar access and shadowing potential of the simulated scenarios for the five orientations in both the stair and pyramid urban typologies.

It is apparent that the $90^{\circ}$ orientation receives more of the available daylight due to high exposure. Although this provides adequate light during the day and cuts down on energy that is consumed for artificial lighting, it also results in increased solar heat ingress that raises the space cooling requirement during the warm season in Shiraz. It can be further deduced that the orientations of $45^{\circ}$ and $135^{\circ}$ provide a balance between daylighting and thermal shading by the placement of the blocks, while the $155^{\circ}$ models experience overshadowing, leading to daylighting below the acceptable requirements [12]. 
The results of the shadowing analysis show that the scenarios with orientations of $0^{\circ}$ and $90^{\circ}$ present less shadow at their sites for both the stair and pyramid typologies compared to the other orientation scenarios.

The presented inferences are further explored through a thermal analysis.

\subsection{Thermal Analysis}

The simulated annual heating and cooling energy consumption results indicate that the $155^{\circ}$ orientation demonstrates a significant decrease in the cooling load, particularly for the pyramid model.

A further comparison between the two urban block typologies shows that the pyramid model performs better than the stair model, as illustrated by the plot in Figure 1. The total annual energy consumption is distinctly reduced in the pyramid case. This can be attributed to the overshadowing angles that are caused by adjacent blocks, which cut down on the incidence of solar radiation on the facades.

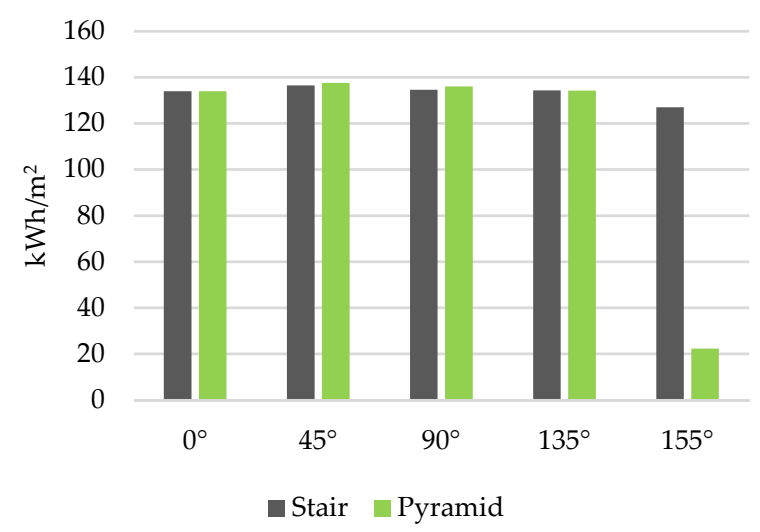

Figure 1. Comparison of total annual energy consumption of the stair and pyramid urban typologies denoting the selected orientations.

\section{Conclusions}

This study discerns the optimal thermal performance of residential apartment blocks by investigating different urban layout options for the city of Shiraz, Iran.

The findings indicate that the pyramid urban model has lower annual cooling and heating energy costs, with the $155^{\circ}$ orientation to be most suitable. However, the $155^{\circ}$ models experience overshadowing, leading to daylighting below the acceptable requirements.

A detailed analysis of the openings and façade materials with suitable insulation levels can provide more accurate results, leading to a precise estimate of energy needs.

Author Contributions: Conceptualization, G.P., M.M. and C.B.; methodology, M.M. and N.V.S.K.M.; software, M.M.; validation, M.M., S.N.S. and N.V.S.K.M.; formal analysis, M.M. and S.N.S.; investigation, G.P., M.M. and C.B.; resources, M.M.; data curation, M.M. and N.V.S.K.M.; writing-original draft preparation, G.P., H.J. and M.M.; writing—review and editing, G.P., H.J., N.V.S.K.M. and C.B.; visualization, M.M.; supervision, G.P. and C.B.; project administration, M.M.; funding acquisition, G.P. All authors have read and agreed to the published version of the manuscript.

Funding: This research received no external funding.

Acknowledgments: The authors would like to thank UNSW and the School of Built Environment for organizing the Built Environment Research Forum and the reviewers for the provided feedback.

Conflicts of Interest: The authors declare no conflict of interest. 


\section{References}

1. Khodamoradi, A.; Sojdei, F. Energy efficiency potentials in Iran: A precise look to one of the biggest energy producers. In Proceedings of the ECEEE 2017 Summer Study-Consumption, Efficiency \& Limits, Belambra Les Criques, Toulon/Hyères, France, 29 May-3 June 2017; pp. 23-27.

2. U.S. Energy Information Administration (EIA). Country Analysis Executive Summary: Iran; EIA: Washington, DC, USA, 2021.

3. Azimi, N.; Esmaeilzadeh, Y. Assessing the relationship between house types and residential satisfaction in Tabriz, Iran. Int. J. Urban Sci. 2017, 21, 185-203. [CrossRef]

4. Ratti, C.; Baker, N.; Steemers, K. Energy consumption and urban texture. Energy Build. 2005, 37, 762-776. [CrossRef]

5. Faizi, F.; Noorani, M.; Ghaedi, A.; Mahdavinejad, M. Design an optimum pattern of orientation in residential complexes by analyzing the level of energy consumption (case study: Maskan Mehr complexes, Tehran, Iran). Procedia Eng. 2011, 21, $1179-1187$. [CrossRef]

6. Lobaccaro, G.; Frontini, F. Solar energy in urban environment: How urban densification affects existing buildings. Energy Procedia 2014, 48, 1559-1569. [CrossRef]

7. Vermeulen, T.; Merino, L.; Knopf-Lenoir, C.; Villon, P.; Beckers, B. Periodic urban models for optimization of passive solar irradiation. Sol. Energy 2018, 162, 67-77. [CrossRef]

8. Kämpf, J.H.; Robinson, D. Optimisation of building form for solar energy utilisation using constrained evolutionary algorithms. Energy Build. 2010, 42, 807-814. [CrossRef]

9. Alamdari, P.; Nematollahi, O.; Alemrajabi, A.A. Solar energy potentials in Iran: A review. Renew. Sustain. Energy Rev. 2013, 21, 778-788. [CrossRef]

10. SOLARGIS Solar Resource Maps 2018. Available online: https://solargis.com/maps-and-gis-data/download/iran (accessed on 3 November 2021).

11. Autodesk Support: Validation of Ecotect Analysis Results. Available online: https://knowledge.autodesk.com/search-result/ caas/sfdcarticles/sfdcarticles/Validation-of-Ecotect-Analysis-results.html (accessed on 7 November 2021).

12. Office of National Building Regulation. National Building Regulation of Iran. Article 19: Optimizing Energy Consumption; Ministry of Housing and Urban Development, Deputy for Housing and Construction, Iran Development Publishing: Tehran, Iran, 2011.

13. Azimi, M. High Standards of Construction; Noavar Publishing: Tehran, Iran, 2015.

14. Najafi, N. Iranian Traditional Architecture and Energy Saving (case study: Shiraz Ghajar Houses). Glob. J. Adv. Pure Appl. Sci. 2013, 1, 940-947.

15. Meteonorm Software. Available online: https://meteonorm.com/en/ (accessed on 7 November 2021). 